\title{
Blended Learning: How Teachers Balance the Blend of Online and Classroom Components
}

\author{
Lynn M. Jeffrey, John Milne and Gordon Suddaby \\ Massey University, New Zealand \\ I.m.jeffrey@massey.ac.nz j.d.milne@massey.ac.nz \\ gtsuddab@gmail.com \\ Andrew Higgins \\ AUT University, New Zealand \\ andrew.higgins@vodafone.co.nz
}

\begin{abstract}
Despite teacher resistance to the use of technology in education, blended learning has increased rapidly, driven by evidence of its advantages over either online or classroom teaching alone. However, blended learning courses still fail to maximize the benefits this format offers. Much research has been conducted on various aspects of this problem, but only one other study has examined teaching practice in a blended course. Teachers using blended learning were interviewed about their use of online and classroom components and the reasons for their decisions. The online and classroom aspects of their course were analysed against a pedagogical framework of engagement strategies. Classroom components were found to be more highly valued by teachers than those online, an attitude largely driven by their perceptions that specific learning functions were best suited to particular formats. The courses themselves reflect these values. Most teachers used well-developed engagement strategies in their classroom teaching, compared to a minimal use of strategies online. Further, with one exception there was a lack of integration between online and classroom components. Blended learning will not fulfill its promise of better learning unless teachers can be encouraged to re-think and redesign courses that afford students more, and different learning experiences than those offered by either online or classroom alone. This paper adds to a small literature base examining what teachers actually do in blended learning, and signals steps that teachers and their institutions might take to build on the opportunities presented by blended learning.
\end{abstract}

Keywords: blended learning, student engagement, teaching practice, teacher resistance to technology.

Material published as part of this publication, either on-line or in print, is copyrighted by the Informing Science Institute. Permission to make digital or paper copy of part or all of these works for personal or classroom use is granted without fee provided that the copies are not made or distributed for profit or commercial advantage AND that copies 1) bear this notice in full and 2) give the full citation on the first page. It is permissible to abstract these works so long as credit is given. To copy in all other cases or to republish or to post on a server or to redistribute to lists requires specific permission and payment of a fee. Contact Publisher@InformingScience.org to request redistribution permission.

\section{Introduction}

Chen, Lambert and Guidry (2010)

found that widespread use of the Web and other Internet technologies in postsecondary education has exploded in the last 15 years. An increasing focus of this trend is blended learning. So popular has the uptake of blended learning been, that it has been called the "new 
normal" in higher education teaching (Norberg, Dziuban, \& Moskal, 2011). Blended learning contexts that integrate physical and virtual components are seen as critical strategies for higher education institutions (Cobcroft, Towers, Smith, \& Bruns, 2006). This trend has intensified since the publication of a meta-analysis of 50 studies that found that while online students performed a little better than face-to-face students, students in courses that blended online and face-to-face components did much better than a straight online course, with an effect size of $+0.35, p<.001$ (Means et al., 2010).

The case for the effectiveness of blended learning derives from the observation that such courses offer students a greater range of affordances that enhance the learning experience beyond that of either online or face-to-face modes alone. Support is offered by Ramsden, (2003) who argued that blended environments increase student choice and this can lead to improved learning. Oliver and Trigwell (2005) also suggest that a blended environment may offer experiences that are not available in non-blended environments and that the nature of these different experiences promote learning. While there is evidence to suggest the potential of blended learning, there is also considerable evidence that most blended learning courses fail to fulfill this potential (Driscoll, 2002; Hofmann, 2006).

This failure can be partially explained by the well-documented resistance of teachers to online learning, a common theme in the literature for at least 15 years (see for example, Heirdsfield, Walker, Tambyah, \& Beutel, 2011), and a lack of adequate professional development (Garrison $\&$ Vaughan, 2008). The profusion of online and blended learning courses have become pervasive in the educational sector, driven by senior administrators who are more positive about the efficacy of online learning than teachers (Allen, Seaman, Lederman, \& Jaschik, 2012). Faculty are often given little option about incorporating online learning components into their classes, so it's not surprising that the results are frequently disappointing.

While there is substantial blended learning literature on the student experience, course design, and even the professional development of teachers, a neglected area is teaching practice: how and why teachers balance the blend of online and classroom components (Torrisi-Steel \& Drew, 2013). In a literature review of over 800 articles, Torris-Steele and Drew (2013) found only one article, by Woods, Baker and Hopper (2004), on academic practice in a blended environment. Knowing more about what teachers do in their teaching practice when they are required to introduce online components may go some way to explaining the failure of blended learning to reach its predicted potential. Only by understanding current practice can we prepare to make changes to that practice.

This study adds to the sparse literature on the practices and attitudes of teaching in blended courses in a qualitative study in which teachers were interviewed about their teaching practice and their attitudes to blended learning. In addition, the effectiveness of their online and classroom components was assessed against a pedagogical framework of student engagement strategies.

\section{Blended Learning}

Blended learning has been described as a mode of teaching that eliminates time, place, and situational barriers, whilst enabling high quality interactions between teachers and students (Kanuka, Brooks, \& Saranchuck, 2009). It echoes the practice of distance education that emphasized flexibility of time, place, and pace of student learning. Research suggests that the student experience varies considerably and results in variable learning experiences (Jeffrey, Kinshuk, Atkins, Laurs, \& Mann, 2006; Zepke, Leach, \& Prebble, 2006), indicating a need to clarify how a blended approach can support learning.

The role of faculty in successful blended or online learning has been noted in a number of studies. Mayes and Morrison (2008) found that, in addition to a well-managed program, it was important 
Jeffrey, Milne, Suddaby, \& Higgins

that teachers are both interested and competent in teaching in an online context. Bates and Sangra (2011) argued that; "There is convincing evidence that online students do just as well if not better than students in face-to-face courses, but more important, the results depend on the conditions in which students are studying. All modes of delivery will suffer from badly designed teaching or inadequate resources" (p. 147).

Technology has increased the breadth and depth of access to education. This is significant because it has been a hallmark of western education that the co-location in time and space of teachers, students, and resources is the sine qua non of education. Changing from a classroom-only context to include a major online component requires adjustment for both teachers and students (Swenson \& Redmond, 2009). The speedy adoption of educational technologies is evidence that new forms of teaching and learning are possible. However, shifts of this magnitude need major changes in approach from faculty and administrators in education, especially in higher education, where the lectures still dominate teaching practice.

\section{Teacher Resistance to Technology}

Despite the clear demonstration of the benefits of using technology in education, there continues to be a marked reluctance by academics to engage with online learning (Anderson, 2008). Heaton-Shrestha, May, and Burke (2009) found teachers to be much less positive than their students about the learning benefits of an online learning component. Becker and Jokivirta (2007) also found that academics worldwide reported low enthusiasm for using technology in learning. More recently, a large-scale study (over 4,500 teachers) by Allen et al. (2012) found that $65 \%$ of faculty were more afraid of teaching with technology than they were excited by the prospect.

Over the past 15 years several factors have been identified as discouraging academic staff from teaching in online environments, including inadequate support and training, time for developing online materials, fears of failure, and beliefs about the value of technology in education.

Mansvelt, Suddaby, O'Hara, and Gilbert (2009) presented findings from an online survey of 408 teachers and 40 qualitative interviews ascertaining beliefs and experiences of staff regarding elearning professional development. They found that managerial support, individual beliefs, and time allocation influenced the attitude of faculty to attending training to improve their use of technology in teaching. Allan (2007) also argued that using online learning for professional development would not be effective unless account was taken of two factors: the extra time involved in networked learning, and for people new to e-learning to adjust to this type of study.

Greener $(2009$, p. 267) reported that "online, the teacher's status can easily be eroded, as learners can compare teacher-designed resources with video lectures from across the world on similar topics and chat directly with experts in the field through their blogs." The potential for such comparisons inclined teachers to be reluctant to expose themselves to ridicule or unflattering comparisons.

A number of studies have found that beliefs about the usefulness and effectiveness of technology influenced whether teachers integrated technology into their teaching (Aslı Özgün-Koca \& İlhan Şen, 2006; MacCallum, 2011). Teachers argue their reluctance to use technology as stemming from a concern for the educational well being of their students. For example, they claim that technology has no beneficial effect on learning and is even instrumental in maintaining students in a state of semi-disengagement (Heaton-Shrestha et al., 2009). The same study reported concern by teachers that technology could decrease student interaction and result in greater social isolation for the student. Christie and Jurado (2009) also found that being convinced of the effectiveness of technology was necessary before teachers would fully engage with it.

Teachers who fail to recognize the benefits of online learning are less likely to create effective blended courses. A negative or indifferent student response to poorly designed online components 
in a blended course may reinforce the teacher's belief that such additions to the traditional classroom have little value.

\section{Measuring Effective Blended Courses}

There are a number of ways of judging the effectiveness of online and classroom teaching practices. One of the most common is measuring student learning. It is less common to evaluate a course against a set of pedagogical principles. An advantage of evaluating courses using recognized criteria is the removal of the third variable problem that comes into play when students' learning outcomes are used as measurement. A number of factors other than teaching effectiveness can influence student learning. Assessing online and classroom components directly against established criteria is a more direct measure of their quality.

Learning results from the quality of student engagement in learning experiences (Dixon, Kuhlhorst, \& Reiff, 2006; Swan \& Shih, 2005). It follows then that teaching practices that foster quality student engagement will result in more effective learning. Jeffrey, Milne, Suddaby, and Higgins (2012) constructed from a comprehensive review of literature, a framework of student engagement strategies found to improve learning. Three major categories of student engagement strategies were identified: getting student attention, maintaining engagement, and re-engaging those who drift away or fail to engage. Most of these strategies are applicable both online and in the classroom, which makes them suitable to measuring blended learning practices. These strategies are described below.

Getting Students Engaged: Capturing student attention at the start of the course is must be achieved before effective learning can take place. Two major types of strategies were identified as being important:

1. Primers for getting student attention: Curiosity, relevance. The literature identifies two possible approaches, curiosity and relevance. Curiosity is experienced as a result of awareness of a knowledge gap, which creates the motivation to find the answer. A topic that has personal relevance to a student stimulates an optimal level of arousal for learning. (Arnone \& Grabowski, 1994; Ashcroft, 1987; Berlyne, 1960; Doo \& Kim, 2000; Keller, 1987; Kift, 2008; Levy, 2007; Loewenstein, 1994; Reeve, 1992; Reio Jr. \& Wiswell, 2000; Shea, Pickett, \& Pelz, 2003)

2. Social presence and belonging: Teacher enthusiasm, immediacy and an inclusive environment.

Students are less likely to feel alienated and more likely to become engaged when they feel a sense of belonging to their class and subject discipline. Teachers play an important role in social presence. This is particularly true of online environments which can be more impersonal students. A sense of teacher immediacy is important to students. (Dixon, et al., 2006; Garrison, 2009; Guan, Tregonning, \& Keenan, 2008; Krause, Hartley, James, \& McInnis, 2005; Swan \& Shih, 2005; Thompson \& MacDonald, 2005; Tinto, 1975, 1993)

Maintaining Engagement: Maintaining student engagement through the course requires four strategies:

3. Clear content structure

At the start of a new course, students expect a clear course outline that includes the content structure and other organizational features. (Beck \& Davidson, 2001; Hunt, Eagle, \& Kitchen, 2004; Light, 2001; MacDonald \& Thompson, 2005) 
4. Clear, unambiguous instructions and guidelines in assessment

The high levels of anxiety that students typically feel about this aspect of the learning process can be alleviated by clear guidelines. (MacDonald \& Thompson, 2005; Madsen \& Turnbull, 2006; Rust, 2002)

5. Challenging, authentic tasks

Challenging tasks encourage the student work to the limits of their ability. Learning results from effort: The greater the effort, the greater the sense of achievement and motivation. Students are also motivated by activities that reflect those in 'real world'. (Brown, Collins, \& Duguid, 1989; Doyle, 1983; Herrington, Oliver, \& Reeves, 2003; Lombardi, 2007; Miller, 2010; Nakamura \& Csikszentmihalyi, 2002)

6. Timely, elaborated feedback

The evidence strongly suggests that in most circumstances feedback that is immediate and specific results in better learning. (Bangert-Drowns, Kulik, Kulik, \& Morgan, 1991; Beach \& Friedrich, 2006; Bransford, Brown, \& Cocking, 2000; Corbett \& Anderson, 2001; Dorow \& Boyle, 1998; Hattie \& Timperley, 2007; Kluger \& DeNisi, 1998; Kulhavy, White, Topp, Chan, \& Dams, 1985; Mason \& Bruning, 2001; Mayer \& Moreno, 2002; Miller, 2010; Wiliam, 2007)

Re-engaging Students: In most courses a proportion of students will delay or fail to engage at the start of the course, or stop engaging during the semester, usually at key points such as assessment. The literature identifies two critical strategies for re-capturing the engagement of these students.

7. Monitoring and early identification

Monitoring students to identify students in danger of dis-engaging or those who have failed to engage, is important to recovering these students. (Fitzgibbon \& Prior, 2003; Gracia \& Jenkins, 2002; Trotter \& Roberts, 2006)

\section{Personal contact and negotiated conditions for re-engagement}

The most effective strategy for re-engaging students is personal contact by the teacher. Such contact works best when the teacher works with the student to provide help and support. (Artino \& Stephens, 2009; Tuckman, 1999; 2007)

These engagement strategies provided a framework for interviewing teachers about their teaching practice in a blended course, and for evaluating the effectiveness of such practices.

\section{Methodology}

This study was part of a larger study on student engagement in a blended learning environment that involved both students and teachers (Jeffrey et al., 2012). The purpose of this part of the study was to:

1. Identify what aspects of their courses teachers put online and what they used in the classroom, and how they explained these decisions.

2. Compare the quality of the online experiences to those of the classroom, using a set of student engagement strategies identified from the literature.

Nine tertiary teachers from two state universities, teaching blended learning courses, were interviewed. The sample included three females and six males, aged between 36 and 60. All were 
experienced teachers with more than 5 years tertiary level teaching. All but one teacher had had previous experience of teaching in a blended context.

Suitable courses were identified and the teachers of those courses invited to take part in the research. The selection of courses was based on the nature of the course (business, large class size) and the timing of the course (all in the same semester). Four additional teachers who were approached were unable to take part for a variety of reasons.

Teachers were interviewed individually (between 1 and 2.5 hours) and asked:

- How they decided what to put online and what to teach face-to-face

- For a detailed description of their classroom teaching (based on the student engagement strategies).

- What they considered to be the advantages and disadvantages of classroom teaching and online teaching.

Content analysis was used to interpret the interview data (Neuendorf, 2002). The transcripts were read and key words and phrases identified and recorded. These were then categorized according to theme and labeled. All data was then sorted according to these categories. Data within each group was then re-sorted into variations on the theme and these sub-groups were also labeled.

Two reviewers evaluated each online learning site (inter-rater reliability was $87 \%$ ). The evaluation sheet used a detailed list of student engagement strategies and each of these was rated using a four-point scale from 0 (not present), 1 (minimal presence), 2 (adequate presence) and 3 (good presence). An overall score was obtained for each of the strategies. The data on the use of engagement strategies used in the classroom was extracted from the interview data and rated in a similar way. These two sets of data were used for rating the two components of each course (online and classroom) on their pedagogical value.

\section{Results}

The decision to put learning content online or use in the classroom seems to be largely driven by the teacher's perception of the functions served by the two modes. Usefulness, ease of use, and student pressure were also considerations.

\section{Different Functions for Classroom and Online Contexts}

Teachers commonly made three distinctions when discussing how they used classroom or online contexts as they saw lectures, tutorials, and online environments as serving different functions. Lectures were considered to be appropriate for teaching theory, and while these could be made more interesting with examples, theory was described by teachers as being dry and abstract but "they're here to learn about theories as well as everything else, that's what university's about, so they've got to have that component [lectures]" (Teacher 5).

Tutorials were regarded as the opportunity for students to interact with theory at an applied level:

There's actually quite a separation between the lecture and the tutorial. The lecture follows the textbook, it's purely knowledge and theory-base, going along closely with the textbook and the slides provided by the publisher. Then there's the tutorial, this is purely applied and problem solving. (Teacher 9)

Almost all teachers saw the lecture as the main forum for the initial teaching of content and tutorials as the consolidation of the lecture through activities. Most teachers also advocated the importance of the set text, for example "I still like the idea of a textbook, a textbook is actually all you need" (Teacher 8). 
Teachers considered that the most important function of their online sites was a central repository for resources, "So everything was online" (Teacher 3). Online content included core content, textbook publisher resources such as slides, PowerPoint notes to be downloaded for the next class, administration information, and other resources such as YouTube videos. Increasing student accessible to these resources was seen as a major advantage of using an online component.

Two distinct but equally strong perceptions on the quantity of material that should be placed online were found. One group favoured large amounts of content, as exemplified by Teacher 8 who expressed particular enthusiasm for putting lots of material online. He felt this reduced pressure on him to cover everything in lectures. He could focus on areas of particular interest and give the topic more depth:

.... and I think it comes back to having multiple avenues to collect information. . . so they've got a textbook there, which very good. And then I've got PowerPoint slides that are complimentary but not the same, well actually if you read all those and understood them they'd actually know the topic well, so that no matter what I do in class technically there's the information there... And I think takes a lot of pressure off me and allows me to actually get down and do the stuff that they want to learn about I suppose. And having it all online means that I don't feel as if I have to point things out in the lecture. (Teacher 8)

About half the teachers felt that too much content online was a problem as it gave students a false sense of security and discouraged them from attending class. It was also felt that too much material had the potential to confuse students.

The ease of putting resources online and the plethora of Web-base resources such as YouTube was offered as a significant factor in using the online learning site as a repository, as explained by one teacher:

It was very easy to put up the core material, including - the textbooks supplied slides. YouTube is very good, I'm finding more and more stuff on YouTube where there's either a video that might explain a point, might have an advert, it might have a discussion or something like that, that I can put online. And if it's like two or three degrees away from the subject or it doesn't absolutely nail what I want to say then I'll put it online and say, "This is an additional resource or additional material to read." (Teacher 3)

Work by Gibbs (1992) identified excessive amounts of course material online as a factor in promoting surface learning in students. Large volumes of materials increase the amount and difficulty of the work the students have to do since they must evaluate and select the most appropriate of these to use. Students can find such a task overwhelming. Gibbs goes on to argue that not only should the amount of online material be moderate, but that it should also be carefully integrated into the learning content.

A number of teachers in this study felt that the online component was a way of reducing some of their administration load. Students in several classes were told to refer to the online site to find information and resources for aspects of the course relating to administration and assessment requirements. Students were urged to check the online site before asking questions of teachers.

All of the courses in the study made forums available, but these were mainly used as one-way communication from the teacher. Very few students used the forums to communicate with each other, despite encouragement from teachers. Teachers valued the ready contact with students provided by forums, a finding that supports Aspden and Helm (2004). However, these messages were only sent as a specific need arose, rather than on a frequent and regular basis as recommended by Ryle and Cummings (2007). 
Four of the courses used online quizzes. All of these generated higher levels of engagement that were sustained throughout most of the semester.

Pressure from students to put material online was mentioned by a number of teachers. For example, Teacher 9 described how he had previously refused to put PowerPoint slides online before classes for students to download.

But students used to complain, and always said, "Why don't we have lecture notes online?" So I finally put them up. But I'm not sure it's beneficial. By giving them the notes they just sit there and are so easily distracted from the lecture itself, they think they can just going through the slides and don't listen to the lecture.

Other teachers supported this position and felt that the practice of providing PowerPoint handouts encouraged students to stop attending class or to regard only the information on the PowerPoint as being of any importance.

\section{Comparing Online and Classroom Application of Engagement Strategies}

Teachers' courses were evaluated on the use of five engagement strategies that appeared in both online and classroom modes.

Table 1: Presence of engagement strategies in online and classroom modes

\begin{tabular}{|c|c|c|c|c|c|c|c|c|c|c|}
\hline \multirow[t]{2}{*}{ Teacher } & \multicolumn{2}{|c|}{ Primer } & \multicolumn{2}{|c|}{$\begin{array}{l}\text { Social } \\
\text { Presence }\end{array}$} & \multicolumn{2}{|c|}{$\begin{array}{l}\text { Challenge, } \\
\text { Authentic } \\
\text { Tasks }\end{array}$} & \multicolumn{2}{|c|}{ Structure } & \multicolumn{2}{|c|}{ Re-engaging } \\
\hline & Online & Class & Online & Class & Online & Class & Online & Class & Online & Class \\
\hline 1 & 1 & 3 & 3 & 3 & 3 & 3 & 3 & 3 & 3 & 3 \\
\hline 2 & 1 & 3 & 2 & 3 & 2 & 3 & 3 & 3 & 3 & 0 \\
\hline 3 & 1 & 3 & 2 & 3 & 0 & 3 & 0 & 1 & 0 & 0 \\
\hline 4 & 2 & 1 & 3 & 3 & 3 & 3 & 2 & 2 & 3 & 0 \\
\hline 5 & 0 & 2 & 1 & 1 & 0 & 1 & 3 & 2 & 0 & 0 \\
\hline 6 & 0 & 3 & 1 & 3 & 0 & 3 & 3 & 3 & 0 & 3 \\
\hline 7 & 0 & 2 & 1 & 1 & 0 & 1 & 2 & 2 & 0 & 0 \\
\hline 8 & 0 & 2 & 1 & 3 & 1 & 2 & 1 & 1 & 0 & 0 \\
\hline 9 & 0 & 3 & 1 & 3 & 3 & 3 & 2 & 2 & 0 & 2 \\
\hline
\end{tabular}

Overall teachers put much more pedagogical effort into developing and using classroom engagement strategies than online. However three teachers (1,2, and 4) come close to a balance between the two modes of teaching. What's more, they generally used high quality strategies. Three more $(5,6$, and 7$)$ were strongly classroom focused, apart from ensuring their online components were clearly structured. These teachers had fewer materials online. Teacher number 6 used very good engagement strategies in class, and these may have compensated for less attention online. The remaining three teachers occupied a middle position. Below is an analysis of the comparison of the engagement strategies in the two modes. 
Jeffrey, Milne, Suddaby, \& Higgins

\section{Primers}

The first stage of engagement involves two components: primers and social presence. Primers are devices or strategies to spark curiosity, interest, and relevance in the subject at the start of the course, while social presence includes the teacher's enthusiasm and the extent to which students feel a part of the class and the discipline. Both of these strategies were applied more often and effectively in the classroom than online.

Primers seemed to be strategies that teachers gave relatively little forethought to. They were largely absent from most online sites, with only four teachers using a specific strategy. In the classroom, most suggested that they used relevance, for example, explaining how this course fitted into the student's overall program or how the skills learned would be useful in the workplace. However, these appeared to be done off the cuff rather than as a carefully thought out strategy. Some teachers used their own backgrounds and anecdotes to connect with the personal experiences of the students. A similar strategy employed by one teacher was to use the first part of a lecture to build the relationship with students, for example, talking informally about a topical issue and inviting students to express their views (Teacher 2). Another teacher (Teacher 8) tried to sell students on the idea that the class is a joint venture by both parties. Generally, teachers did not get hugely enthusiastic about this issue, which is summed up in the following quote:

...it's fairly much business as usual. I think what I'll do is I go in there and I'll outline the course and my expectations; what they have to do and give them the sort of advice that would be useful in the course, but I don't think I necessarily would go out of my way to you know kind of, attract the students to the course because at the end of the day they've made that call. (Teacher 4)

There is extensive literature on the importance of curiosity and personal relevance to learning (see for example, Doo \& Kim, 2000; Keller, 2010; Levy, 2007; Shea, et al., 2003). These strategies are most important early in the course, when students fail to engage. Experts readily identify gaps in their knowledge and so experience high levels of curiosity that drives them to pursue information to fill those gaps (Loewnestein, 1994). Students, however, have lower levels of curiosity, so teachers must use strategies to prime the curiosity pump and stimulate an interest in knowledge.

Students see learning as relevant when it appears to have the ability to help them achieve personal goals. When students fail to make the connection between learning content and their own aspirations, they are much less likely to pay attention to it (Murray \& Sandars, 2009). In addition, a lack of personal relevance has been found to be related to higher student dropout rates (Levy, 2007; Park \& Choi, 2009). Consequently, demonstrating relevance at the first opportunity is critical to the learning process.

\section{Social presence}

Establishing social presence in the classroom clearly comes from the interaction between teachers and students. Most teachers described positive engagement with their students in the classroom and often made a concerted effort to develop a relationship with their students. For example, several teachers started the class by establishing a dialogue with students. This might involve them telling the students about themselves, for example, their personal interests and their experience and background in the subject area. Most teachers also expressed in interest in finding out more about their students and would spend some time in class asking them questions, for example, about their motivation for taking the class and what they hoped to achieve. Two teachers scored quite low on the use of this social presence in the classroom. Both of these teachers seemed to hold quite negative views about students and had issues interacting with students and managing their behavior. "So, I feel like I can't control the classes to the degree that I want to in order to 
enable them to be able to do what they can do" (Teacher 5). This teacher also described students as "lazy".

Establishing a social presence online is much more difficult than in the classroom, so it was not surprising to find that social presence was largely underdeveloped in most of the study's online environments. All online sites had teacher contact details, a welcome message, and a discussion forum, but these took an informational tone and it was hard to get a sense of the teacher from them. Wang and Newlin (2002) emphasis the importance of the social presence of teachers, especially to those students vulnerable to dropping out. Social presence online is felt as a sense of immediacy and intimacy in the way teachers communicate with their students.

Forums were used by all teachers to contact students, and this was an aspect of the online site that they valued, a finding that agrees with Aspen and Helm (2004). However, these messages were sent on an 'as-needed' basis, and Ryle and Cumming (2007) suggest that they are most effective at embodying teacher presence when communication is frequent and regular.

Two teachers emphasised the care they took to establish a relationship when communicating with students. One of these teachers explained, "I believe when I come to work each morning if someone has taken the time to ask a question, I answer it then and there. I don't have a set time each day where I sit down and say right I'm only going to do $x$ number of questions and any questions after that will not be answered. I tend to find my personal philosophy [is that] I answer questions inside, as well outside, of work hours [and] I think that it really goes a long way towards students developing a kind of trust'(Teacher 4).

He justifies his attention to student questions because he believes that if "you give them a fairly quick response then they'll feel like they can then approach you, so its not a barrier, ... I think they should be able to ask if they're not sure and then that way they gain confidence". For this teacher, feedback to students was an opportunity to build a relationship with them and to break down barriers that could potentially hinder their learning.

Teacher 1 posted all of her responses to questions from individual students online so that everyone had the benefit of the answer. These responses are supplemented with additional teaching notes. This teacher also made a point of personalizing her responses to students "as if I'm talking to them," and using the student's name. When students start to use her name in their questions, then she feels she has made a connection.

\section{Maintaining Engagement using Motivation}

Two types of strategy that work by motivating students are the use of challenging, authentic tasks and providing personal, timely, and quality feedback.

\section{Challenging, authentic tasks}

Most teachers described assessment tasks that were challenging and authentic. They involved students interacting with material that was derived from the real world, such as case studies, or with practitioners who brought a business problem to be solved. However, there was more variability between courses in their online learning activities, as opposed to either classroom activities or assessment activities.

Only four teachers had developed online activities, most of which took the form of online quizzes. The levels of student engagement with these activities were very high and sustained over the semester. All teachers used classroom activities; however, several teachers reported frustration at poor attendance at these. Those students who did attend often showed little inclination to take part in the activities. Many failed to bring writing materials and even when provided with these, failed to complete the task. Teacher 5, who had a particular problem with attendance, described her ac- 
tivities as 'fun' (cf 'authentic tasks'). She had modified these activities from ideas picked up from other courses. However, many of these activities where of the type found at training courses and didn't always seem to be directly related to the substance of the course content.

One teacher who had high online engagement with quizzes and high attendance in class described his course as being "challenging" as it involved a close integration of theory and problem solving. He believed that the problem solving, which is done in the tutorials, is essential as it is only when the students work through problems that they realize whether or not they understand the theory. When students appear to be struggling he invites them to "Come to the whiteboard, we will solve this together" (Teacher 9) and he works with the student to solve the problem. The teacher closely monitors student engagement with the set problems; "it's not a class you can hide in". Students found this course "one of the hardest classes they've done but one of the most rewarding ones".

Teacher 3 described a similar response to a challenging, authentic, group-based assessment task. He found students willing to 'pull all-nighters' when working on their assessments. He reported students as commenting they "had never worked so hard on an assignment but had not enjoyed one so much". Brophy (1987) argued that challenging academic tasks promote motivation when students expend effort through engagement in sustained activity that use complex cognitive processes, a conclusion endorsed by Miller (2010).

\section{Maintaining Engagement through Organisation and Structure}

Seven of the nine online learning sites were well or adequately organized and structured. These were divided into appropriate chunks, easy to navigate, followed a logical structure, and had clear guidelines and instructions.

Most teachers described their classroom teaching as being carefully structured for the semester and for each lecture. This structure was also reflected in their online sites. Two teachers, however, argued a need to be flexible rather than following a rigid program, to allow them to be responsive to opportunities that arise in class and the need to cut out portions of the lecture if time had been spent on exploring other issues that cropped up. They managed this process by skipping PowerPoint slides, jumping back and forth between slides, or bringing in new material. One teacher even colour-coded his slides to facilitate this flexible process as "timing things doesn't work out so a lot of it was hopping about the topic...I was very aware that we had certain material we needed to get through" (Teacher 8).

Despite complaints from students, these lecturers felt that this type of flexibility enhanced their teaching. As one commented:

Because our students are very diverse .... and I think if I had gone in there quite rigidly either doing just lectures or just doing presentations or even having a very, very strict schedule it wouldn't have worked. (Teacher 8)

The online sites of these two teachers reflected the lack of structure they described in their lectures. One in particular had no apparent structure and used a variety of colors, levels, and font sizes that did not seem to follow any logical order. Resources from a variety of sources were added, with no attempt to integrate or explain how to use them. For example, a large portion of another course (with a different teacher) was added with a little explanation of how it was to be used. No attempt was made to 'fit' or adapt this content for the course.

A third teacher had expressed a preference for this type of flexibility but changed his approach in response to student feedback:

Students don't like the lecturer changing the pace of a lecture by skipping slides. You give them these slides and then you realize that oh, there's slightly more here why don't I pro- 
vide another example by spending more time here, but then you run out of time and then you skip the next four slides and then the student says, "But you didn't do this slide." So, if it wasn't for the constant complaints and an expectation, I would still prefer not to give them lecture notes." (Teacher 9)

These results reflect those of others on student preference for structure. Students prefer wellorganized courses (Hunt, et al., 2004; Light, 2001) and dislike ambiguity (Madsen \& Turnbull, 2006). Evidence suggests that that carefully structured courses increase student confidence and competence (Thompson \& MacDonald, 2005) and are an important determinant of a students' tendency to follow a deep or surface learning approach (Rust, 2002). Such structure and support is even more important in an online environment, where the normal social and contextual cues of the classroom are missing (Garrison \& Arbaugh 2007).

\section{Re-Engaging Students: Monitoring, Personal Contact, and Negotiated Study}

Most teachers reported poor levels of class attendance, some as low as $25 \%$. They felt this was due to the over-provision of online materials, which allows students to believe they didn't need to attend class. A number of teachers favored reducing the online material but felt pressured by students to provide it. Teachers in a study by Heaton-Shrestha et al. (2009) expressed similar concerns. They argued that uploading PowerPoint outlines influenced student decisions not to attend class. Agreeing with the teachers in this study, they claimed that such materials created boundaries for student about what content was important and so students failed to explore ideas or material beyond of these narrow boundaries.

Despite the concern with classroom attendance, teachers in this study did not actively monitor student engagement. They felt that their demeanor in class, "I hope I seem inclusive in class" (Teacher 8), and regular invitations to contact the teacher if they had problems, "before each assessment is due I send at least one reminder out and say 'hey by the way the assignment is due, go in it have a look and get questions asked"' (Teacher 3) was enough to encourage those students who needed help to seek it. Several teachers mentioned the importance of a good relationship with students to encouraging them to meet with the teacher when they had a problem: "I try to touch base with different sorts of people in the class breaks (Teacher 8). This teacher became concerned very early about engagement by international students and "so I made an effort in the first class break to talk" to them.

Teachers mostly waited for students to take the initiative to come and see them about problems, "And so they either came to me as a group or individuals came to me squealing or concerned about they felt they had been persecuted ... why did they get such bad marks and so I'd explain to them how the assessment worked" (Teacher 3).

Three teachers actively monitored student engagement online. Mostly, this was through the submission of assignments online, for example:

The first thing that we did in this paper was we asked students to submit the first part of an assignment in week 4. And that was probably the strongest thing that identified students who were withdrawing. I sent an email to all students that had not submitted within two to three days of the submission being due saying 'I noticed you haven't submitted, please contact me if there's a problem'. And from that about six students, sent me an email almost straight away saying 'terribly sorry my life's falling apart, this is what's going on.' (Teacher 1)

These teachers all actively followed up such monitoring by personally emailing the students to ask if there was a problem and could they help. These teachers re-captured the engagement of 
most students, though this sometimes took more than one email. These courses had the lowest dropout rates. The results suggest there is a period during which students who become unhappy with their studies can be re-engaged if they are contacted before making the final decision to withdraw. As found by others, the key is early identification, personal contact, and the negotiation of a workable solution for the student (Fitzgibbon \& Prior, 2003; Trotter \& Roberts, 2006).

Two other teachers used classroom attendance or the physical submission of assignments to identify dis-engaging students and also reported being able to draw students back into the course. However, most teachers in the study did not regard the suggestion that they should take attendance rolls in class with any enthusiasm. They believed that students were responsible for making their own decisions about attendance. The literature, however, emphasizes the importance of taking attendance, both to improve attendance and for early identification of potential disengagement (Trotter \& Roberts, 2006). Monitoring engagement is much easier online, as most Learning Management Systems provide teachers with instant reports on student online activity and provide facilities for contacting students.

\section{Advantages and Disadvantages of Online versus Classroom Teaching}

Teachers' decisions to use online or classroom components were also driven by the perceived advantages and disadvantages of both modes. All teachers agreed that both classroom and online teaching offered benefits to learning. As a repository, the online environment did not suffer the time and space limitations of a classroom. It was also regarded as an excellent mechanism for rapidly contacting all students: "the great thing about it is that you can put stuff in it that students can access from any time anywhere. I can broadcast out quickly out to students saying 'I've just found this, 'or 'Your results are now available'”' (Teacher 3). However, teachers also had reservations. Several teachers described themselves as "old fashioned" which usually prefaced a statement about their personal preference for classroom teaching:

I know I'm old fashioned, but my talking in class is more powerful than something happening online. So I still feel as if I can make more of a difference in class than I can online. So I suppose because I have that belief I'm using the Learning Management System as complementary to the classroom. (Teacher 8)

Another teacher also felt that an online component could complement the classroom, but had limitations:

I think it is useful but I think it needs to be in its place and I don't think it can replace classroom contact and individual argument and engagement with individuals in tutorials, I really don't. I think it's very, very useful for making announcements and making sure everybody knows that something is cancelled or something has suddenly been set up and for providing links to extra readings and so on. I think that's great, but it doesn 't, it can't replace what the university experience is about. I wouldn't want to see computer-based learning and interaction replacing classroom stuff when you can have the classroom stuff. (Teacher 5)

Only one teacher noted the ability of an online component to foster multiple approaches to learning. She argued that class lectures move at one pace, which may be too fast for students who are shy about asking questions. Additionally, some issues may not be completely covered in class. The online environment allowed her to make available extra teaching notes and write answers to student questions, extending the teaching in the classroom. This facility was a major consideration in her decision to expend effort developing a course that fully integrated both classroom and online components. 
Teachers gave one explanation for the limited use of the online component as a lack of time.

I suppose if anything, the biggest obstacle is time... so the time commitment to the actual maintenance of the site; answering questions being available does take time and there's no doubt it does have an impact on your other responsibilities and commitments. (Teacher 4)

Teachers felt frustrated they did not have time to learn to use the system properly nor to be able to personalize it to reflect their approach to teaching and learning.

I haven't got enough time to learn how to use it properly. I think I'm only using maybe 20 or 30 percent of what its real potential is for me as a teacher. And I know I need to sit down and really learn the system but I haven't had time to do more than emergency learning which is not ideal for anybody and leads to problems... Some of the stuff that I've put together I quite like. Some of the stuff where I was kind of obliged time-wise to use more of other people's work than my own I'm not that happy with, not because it's not right but because I want to come with my own twist and I haven't been able to put my own twist on it. (Teacher 5)

\section{Conclusions}

The emergence of blended learning is a major trend in tertiary education (Bliuc, Goodyear, \& Ellis, 2007). This trend is being fueled by the accumulation of evidence that points to the efficacy of a blended approach over either online or classroom alone (Oliver \& Trigwell, 2005). However, there is a danger that blended learning courses will fall far short of the potential if teachers do not change their attitudes and practices to developing blended experiences.

In the main, teachers neither fully exploited the opportunities offered by online contexts nor integrated the two modes to make their courses coherent for their students. Only one teacher in this study recognized the importance of developing a course that fully integrated both online and classroom components. She thought about the strengths of both teaching modes and designed her course to fit with these. Other teachers added an online component to an existing classroom course. They expressed reservations about the role of technology and argued that the teacher should be the central actor, with technology playing a minor support role. These teachers seemed to view online technologies as being mainly for access and information delivery efficiency rather than to support students' learning experiences.

Developing content for two contexts increases teacher workload, and teachers complained about the time commitments necessary to develop even minimal online components. This is an issue that must be addressed by institutions. The benefits of a blended environment will only be realized when multiple engagement opportunities afforded by the two contexts are developed to present students with a range of different experiences, individually and collaboratively. A critical aspect of this development is the integration of the online and classroom components. As others have pointed out, the key to a successful blended learning design is the "thoughtful integration of classroom face-to-face learning experiences with on-line learning experiences" (Garrison \& Kanuka, 2004, p. 96).

In 1986 Shuell said, "It is helpful to remember that what the student does is actually more important in determining what is learned than what the teacher does" (p. 429). We agree with this mostly; but we would add "what the teacher does first strongly influences what the students do". Teachers are the gatekeepers to learning experiences.

Teachers through their selection and design of learning experiences will influence the nature and quality of student learning. What students learn is determined by what they have the opportunity to DO when they engage in the experiences and activities designed by teachers. 


\section{Limitations}

The major limitation of this study is the small sample size. However, this was intended to probe and understand what blended learning teachers do and why they do it, a much-neglected area in the literature. The relatively low adherence of teachers to good design practices in their courses would need a larger scale study to get a sense of how common this is. Additionally, this study was limited to business courses, so needs to be repeated in other discipline areas.

\section{References}

Allan, B. (2007). Time to learn?: E-learners' experiences of time in virtual learning communities. Management Learning, 38(5), 557-572. doi: 10.1177/1350507607083207

Allen, I. E., Seaman, J., Lederman, D., \& Jaschik, S. (2012). Conflicted: Faculty and online education, 2012. Babson Park, MA: Inside Higher Ed \& Babson Survey Research Group.

Anderson, C. (2008). Barriers and enabling factors in online teaching. International Journal of Learning, 14(12), 241-246.

Arnone, M. P., \& Grabowski, B. (1994). Effects on children's achievement and curiosity of variations in learner control over an interactive video lesson. Educational Technology Research and Development, $42(1), 5-20$.

Artino, A. R., \& Stephens, J. M. (2009). Academic motivation and self-regulation: A comparative analysis of undergraduate and graduate students learning online. Internet \& Higher Education, 12(3/4), 146151. doi: 10.1016/j.iheduc.2009.02.001

Ashcroft, E. R. (1987). An evaluation of traditional staff development practices for implementing change in university teaching. Ph D thesis, Massey University, Palmerston North, New Zealand.

Aslı Özgün-Koca, S., \& İlhan Şen, A. (2006). The beliefs and perceptions of pre-service teachers enrolled in a subject-area dominant teacher education program about "Effective Education". Teaching and Teacher Education, 22(7), 946-960.

Aspden, L., \& Helm, P. (2004). Making the connection in a blended learning environment. Educational Media International, 41(3), 245-252. doi: 10.1080/09523980410001680851

Bangert-Drowns, R. L., Kulik, C. C., Kulik, J. A., \& Morgan, M. T. (1991). The instructional effect of feedback in test-like events. Review of Educational Research, 61(2), 213-238.

Bates, A. W. T., \& Sangra, A. (2011). Classroom assessment techniques. San Francisco: Josey Bass.

Beach, R., \& Friedrich, T. (2006). Response to writing. In C. A. MacArthur, S. Graham \& J. Fitzgerald (Eds.), Handbook of writing research. New York: Guilford.

Beck, H. P., \& Davidson, W. D. (2001). Establishing an early warning system: Predicting low grades in college students from a survey of academic orientations scores. Research in Higher Education, 42(6), 709-723.

Becker, R., \& Jokivirta, L. (2007). Online learning in universities: Selected data from the 2006 Observatory report. London: Observatory on Borderless Higher Education (OBHE).

Berlyne, D. E. (1960). Conflict, arousal and curiosity. New York: McGraw-Hill.

Bliuc, A.-M., Goodyear, P., \& Ellis, R. A. (2007). Research focus and methodological choices in studies into students' experiences of blended learning in higher education. The Internet and Higher Education, 10(4), 231-244. doi: DOI: 10.1016/j.iheduc.2007.08.001

Bransford, J. D., Brown, A. L., \& Cocking, R. R. (2000). How people learn: Brain, mind, experience, and school. Washington, DC: National Academies Press.

Brophy, J. (1987). On motivating students. In D. Berliner \& B. Rosenshine (Eds.), Talks to teachers (pp. 201-245). New York: Random house. 
Brown, J. S., Collins, A., \& Duguid, P. (1989). Situated cognition and the culture of learning. Educational Researcher 18(1), 32-42.

Chen, P.-S. D., Lambert, A. D., \& Guidry, K. R. (2010). Engaging online learners: The impact of Webbased learning technology on college student engagement. Computers \& Education, 54(4), 1222-1232. doi: 10.1016/j.compedu.2009.11.008

Christie, M., \& Jurado, R. G. (2009). Barriers to innovation in online pedagogy. European Journal of Engineering Education, 34(3), 273-279.

Cobcroft, R., Towers, S., Smith, J., \& Bruns, A. (2006). Mobile learning in review: Opportunities and challenges for learners, teachers, and institutions. Proceedings of Online Learning and Teaching (OLT) Conference 2006, 26 September 2006, Queensland University of Technology, Brisbane (pp. 21-30).

Corbett, A. T., \& Anderson, J. R. (2001). Locus of feedback control in computer-based tutoring: Impact on learning rate, achievement and attitudes. Paper presented at the ACMCHI 2001 Conference on Human Factors in Computing Systems, New York.

Dixon, M., Kuhlhorst, M., \& Reiff, A. (2006). Creating effective online discussions: Optimal instructor and student roles. Journal of Asynchronous Learning Networks, 10(3), 15-28.

Doo, M., \& Kim, Y. (2000). The effect of relevance-enhanced messages on learning in Web-based training. Korean Association for Educational Information and Broadcasting, 6(2), 73-90.

Dorow, L. G., \& Boyle, M. E. (1998). Instructor feedback for college writing assignments in introductory classes. Journal of Behavioral Education, 8(1), 115-129.

Doyle, W. (1983). Academic work. Review of Educational Research, 53(2), 159-199.

Driscoll, M. (2002). Blended learning: Let's get beyond the hype. Retrieved 25 November, 2013 from http://www-07.ibm.com/services/pdf/blended learning.pdf

Fitzgibbon, K., \& Prior, J. (2003). Student expectations and university interventions: A timeline to aidundergraduate student retention. Paper presented at the LTSN BEST Conference, Brighton.

Garrison, D. R. (2009). Communities of inquiry in online learning: Social, teaching and cognitive presence. In P. Rogers, G. Berg, J. Boettcher, C. Howard, L. Justice \& S. Karen (Eds.), Encyclopedia of distance learning (2nd ed., Vol. 1, pp. 352-355). Hershey, PA: IGI Global.

Garrison, D. R., \& Arbaugh, J. B. (2007). Researching the community of inquiry framework: Review, issues, and future directions. The Internet and Higher Education, 10(3), 157-172.

Garrison, D. R., \& Kanuka, H. (2004). Blended learning: Uncovering its transformative potential in higher education. The Internet and Higher Education, 7(2), 95-105.

Garrison, D. R., \& Vaughan, N. D. (2008). Blended learning in higher education : Framework, principles, and guidelines (1st ed.). San Francisco: Jossey-Bass.

Gibbs, G. (1992). Improving the quality of student learning. Bristol: Technical and Educational Services.

Gracia, L., \& Jenkins, E. (2002). An exploration of student failure on an undergraduate accounting programme of study. Accounting Education, 11(1), 93-107.

Greener, S. (2009). e-Modelling - Helping learners to develop sound e-learning behaviours. Electronic Journal of e-Learning, 7(3), 265-272.

Guan, J., Tregonning, S., \& Keenan, L. (2008). Social interaction and participation: Formative evaluation of online CME modules. Journal of Continuing Education in the Health Professions, 28(3), 172-179.

Hattie, J., \& Timperley, H. (2007). The power of feedback. Review of Educational Research, 77(1), 81-113.

Heaton-Shrestha, C., May, S., \& Burke, L. (2009). Student retention in higher education: What role for virtual learning environments? Journal of Further \& Higher Education, 33(1), 83-92. doi:

$10.1080 / 03098770802645189$ 
Heirdsfield, A., Walker, S., Tambyah, M., \& Beutel, D. (2011). Blackboard as an online learning environment: What do teacher education students and staff think? Australian Journal of Teacher Education, 36(7), 1-16.

Herrington, J., Oliver, R., \& Reeves, T. C. (2003). Patterns of engagement in authentic online learning environments. Australian Journal of Educational Technology, 19(1), 59-71.

Hofmann, J. (2006). Why blended learning hasn't (yet) fulfilled its promises: Answers to those questions that keep you up at night. In C. J. Bonk \& C. R. Graham (Eds.), Handbook of blended learning: Global perspectives, local designs. San Fancisco, CA: Pfeiffer.

Hunt, L. M., Eagle, L. C., \& Kitchen, P. J. (2004). Marketing education and information technology: Matching needs or needing a better match? Journal of Marketing Education, 26(1), 75-88.

Jeffrey, L. M., Kinshuk, Atkins, C., Laurs, A., \& Mann, S. (2006). e- Learning profiles: Diversity in learning. Auckland: Massey University.

Jeffrey, L. M., Milne, J., Suddaby, G. \& Higgins, A. (2012). Strategies for engaging students: Help and hindrances in a blended learning environment (pp. 120). Wellington, NZ: Ako Aotearoa National Centre for Tertiary Teaching Excellence.

Kanuka, H., Brooks, C., \& Saranchuck, N. (2009). Flexible learning and cost effective mass offerings. Paper presented at the Improving University Teaching (IUT), Vancouver, CA.

Keller, J. M. (1987). Development and use of the ARC model of instructiuonal design. Journal of Instructuonal Development, 10(3), 2-10.

Keller, J. M. (2010). Motivational design for learning and performance: The Arcs model approach. New York: Springer.

Kift, S. (2008). Relevance, equivalence and progression in an adult basic education curriculum for Botswana. Paper presented at the The 11th Pacific Rim First Year in Higher Education Conference. 30 June-2 July., Hobart, Tasmania.

Kluger, A. N., \& DeNisi, A. (1998). Feedback interventions: Toward the understanding of a double-edged sword. Current Directions in Psychological Science, 7(3), 67-72.

Krause, K., Hartley, R. J., James, R., \& McInnis, C. (2005). The first year experience in Australian universities: Findings from a decade of national studies. Canberra: Australian Department of Education, Science and Training.

Kulhavy, R. W., White, M. T., Topp, B. W., Chan, A. L., \& Dams, J. (1985). Feedback complexity and corrective efficiency. Contemporary Educational Psychology, 10(3), 285-291.

Levy, Y. (2007). Comparing dropouts and persistence in e-learning courses. Computers \& Education, 48(2), 185-204.

Light, R. P. (2001). Making the most of college: Students speak their minds. Boston: Harvard University Press.

Loewenstein, G. (1994). The psychology of curiosity: A review and reinterpretation. Psychological Bulletin, 116(1), 75-98.

Lombardi, M. M. (2007). Authentic learning for the 21st Century: An overview.

MacCallum, K. (2011). Influences on the adoption of mobile technology by students and teachers. $\mathrm{PhD}$ thesis, Massey University, Auckland.

MacDonald, C., \& Thompson, T. (2005). Structure, content, delivery, service, and outcomes: Quality elearning in higher education. The International Review Of Research In Open And Distance Learning, $6(2)$.

Madsen S. R., \& Turnbull, O. (2006). Academic service learning experiences of compensation and benefit course students. Journal of Management Education, 30(5), 724-742. 
Mansvelt, J., Suddaby, G., O'Hara, D., \& Gilbert, A. (2009). Professional development: Assuring quality in e-learning policy and practice. Quality Assurance in Education, 17(3), 233-249. doi: $10.1108 / 09684880910970641$

Mason, B. J., \& Bruning, R. (2001). Providing feedback in computer-based instruction: What the research tells us. Retrieved on 8 May 2011 from http://dwb.unl.edu/Edit/MB/

Mayer, R. E., \& Moreno, R. (2002). Aids to computer-based multimedia learning. Learning and Instruction, 12(1), 107-119.

Mayes, T., \& Morrison, D. (2008). You take the high road: National programmes for the development of elearning in Higher Education. Reflecting Education, 4(1), 6-16.

Means, B., Toyama, Y., Murphy, R., Murphy, R., Bakia, M., \& Jones, K. (2010). Evaluation of evidencebased practices in online learning: A meta-analysis and review of online learning studies. Washington, D.C.: U.S. Department of Education.

Miller, S. D. (2010). How high- and low-challenge tasks affect motivation and learning: Implications for struggling learners. Reading \& Writing Quarterly, 19(1), 39-57.

Murray, C., \& Sandars, J. (2009). e-Learning in medical education: Guide supplement 32.2 - Practical application. Medical Teacher, 31, 401-402.

Nakamura, J., \& Csikszentmihalyi, M. (2002). The concept of flow. In C. R. Snyder \& S. J. Lopez (Eds.), Handbook of positive psychology (pp. 89-104). Oxford: Oxford University Press.

Neuendorf, K. A. (2002). The content analysis guidebook. Sage.

Norberg, A., Dziuban, C. D., \& Moskal, P. D. (2011). A time-based blended learning model. On the Horizon, 19(3), 207-216.

Oliver, M., \& Trigwell, K. (2005). Can'Blended Learning'Be Redeemed? E-Learning and Digital Media, $2(1), 17-26$.

Park, J.-H., \& Choi, H. J. (2009). Factors influencing adult learners' decisions to drop out or persist in online learning. Educational Technology \& Society, 12(4), 207-217.

Ramsden, P. (2003). Learning to teach in higher education. London: RoutledgeFalmer.

Reeve, J. (1992). Understanding motivation and emotion. Orlando: Harcourt Brace.

Reio, T. G., Jr., \& Wiswell, A. K. (2000). Field investigation of the relationship among adult curiosity, workplace learning, and job performance. Human Resource Development Quarterly, 11(1), 5-30.

Rust, C. (2002). The impact of assessment on student learning. Active Learning in Higher Education, 3(2), $145-158$.

Ryle, A., \& Cumming, K. (2007). Reflections on engagement in online learning communities. International Journal of Pedagogies and Learning, 3(3), 35-46.

Shea, P. J., Pickett, A. M., \& Pelz, W. E. (2003). A follow-up investigation of "teaching presence" Journal of Asynchronous Learning Networks, 7(2), 61-80.

Shuell, T. J. (1986). Cognitive conceptions of learning. Review of Educational Research, 56, 411-436.

Swan, K., \& Shih, L. (2005). On the nature and development of social presence in online course discussions. Journal of Asynchronous Learning Networks, 9(3), 115-136.

Swenson, P. W., \& Redmond, P. A. (2009). Online, hybrid, and blended coursework and the practice of technology-integrated teaching and learning within teacher education. Issues in Teacher Education, $18(2), 3-10$.

Thompson, T. L., \& MacDonald, C. J. (2005). Community building, emergent design and expecting the unexpected: Creating a quality eLearning experience. The Internet and Higher Education, 8(3), 233249. 
Jeffrey, Milne, Suddaby, \& Higgins

Tinto, V. (1975). Dropout from higher education: A theoretical synthesis of recent research. Review of Educational Research, 45(1), 89-125.

Tinto, V. (1993). Leaving college: Rethinking the causes and cures of student attrition (2nd ed.). Chicago: University of Chicago Press.

Torrisi-Steele, G., \& Drew, S. (2013). The literature landscape of blended learning in higher education: The need for better understanding of academic blended practice. International Journal for Academic Development, 18(4), 371-383.

Trotter, E., \& Roberts, C. A. (2006). Enhancing the early student experience. Higher Education Research \& Development, 25(4), 371-386.

Tuckman, B. W. (1999). Conducting educational research (5th ed.). New York: Wadsworth Group.

Tuckman, B. W. (2007). The effect of motivational scaffolding on procrastinators' distance learning outcomes. Computers \& Education, 49(2), 414-422.

Wang, A. Y., \& Newlin, M. H. (2002). Predictors of performance in the virtual classroom: Identifying and helping at-risk cyber-students. TH E Journal, 29(10), 21.

Wiliam, D. (2007). Keeping learning on track: Classroom assessment and the regulation of learning. In F. K. J. Lester (Ed.), Second handbook of mathematics teaching and learning (pp. 1053-1098). Greenwich, CT: Information Age Publishing.

Woods, R., Baker, J. D., \& Hopper, D. (2004). Hybrid structures: Faculty use and perception of web-based courseware as a supplement to face-to-face instruction. Internet and Higher Education, 7, 281-297.

Zepke, N., Leach, L., \& Prebble, T. (2006). Being learner centred: one way to improve student retention? Studies in Higher Education, 31(5), 587-600.

\section{Biographies}

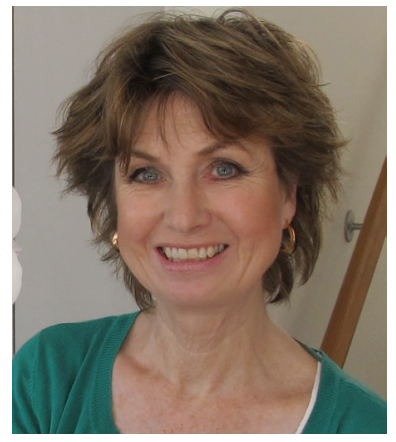

Lynn Jeffrey is an Associate Professor at the School of Management in Massey University (New Zealand). The focus of her research is in improving learning and teaching, and understanding the role that technology might play in achieving that end. Technology that she's developed includes a computer-based, examination-on-demand system (CALES) which was used by the New Zealand Civil Aviation Authority for pilot theory examinations; a learning style website that can be used by tertiary students to get advice on improving their learning and by their teachers for developing more relevant teaching methods; a learning style evaluation website for workplace training; and a webbased simulation game for teaching equity in the workplace. Her current research focuses on student engagement in blended learning environments, mobile learning, integral learning and teaching international students.

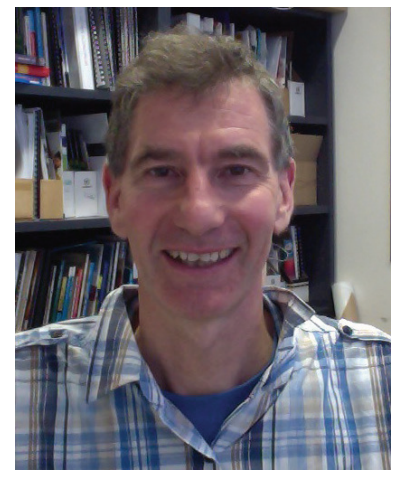

John Milne. Most of John's career has been supporting academics to innovate their teaching. In his currently role, as a teaching consultant, much of his work is to help staff use technology to enhance learning. This includes developing and facilitating academic development sessions and providing intensive individual consultations to design and redesign courses. John's research area is to enhance teaching and learning through the use of technology. This has included work on elearning guidelines, tools for formative assessment, and blended learning and student engagement. He has worked in the tertiary sector in New Zealand and in the UK where he was at the University of Edinburgh and then at the Aberdeen University. 


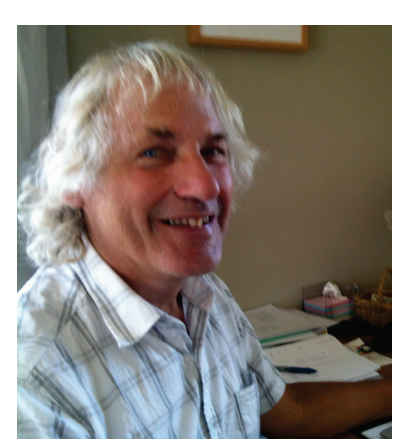

Associate Professor Gordon Suddaby. Gordon has recently retired from his position as Associate Professor, Scholarship of Teaching and Learning at Massey University in New Zealand. Prior to that he was Director, Academic Development and ELearning at Massey for 10 years. In that role he led a team responsible for academic and staff development across the University, for supporting Massey's extensive Distance Education programme and for supporting and promoting Massey's elearning and flexible delivery options. Gordon was president of the Australasian Council on Open, Distance and Elearning for four years. As president of ACODE, and in association with Professor Mike Keppell, president of Ascilite, and Natasha Hard, Gordon produced a Good Practice Report on Technology-Enhanced Learning and Teaching for the Australian Learning and Teaching Council (ALTC) and is currently completing a major ALTC legacy project entitled Network of Australasian Tertiary Associations (NATA). Gordon has a strong interest in quality issues and is currently an Academic Auditor with the New Zealand Academic Quality Agency. He was an auditor for the Australian Universities Quality Agency (AUQA) before its replacement by TEQSA and is a current member of the TEQSA Experts register. He is also an International Reviewer for the QAA (Scotland) and a member of the panel just completing the University of Strathclyde ELI.

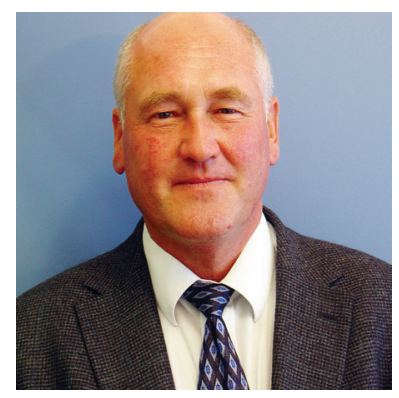

Dr Andrew Higgins was Director of E Learning on the senior management team at the Auckland University of Technology. His background includes many years service with the Queensland Government in Australia, working variously in the Office of the Cabinet, as senior policy officer with Education Queensland, as Manager of the Queensland Police Service's Distance Education program, as Services Officer for AccessEd., as Co-ordinator of the Rural Secondary Schools Support Scheme and as a teacher. He has held appointments at the University of Western Australia, James Cook University and the University of Queensland. He holds the degrees PhD, MEd, BEd and a Diploma of Teaching. His main area of study was in the provision of education to remote and isolated students. Andrew has been President of DEANZ and of the Australian Rural Education Research Association. He was a member of the Ministerial Advisory Committee on E Learning, the national Tertiary E Learning Reference Group and the Ministry of Education's Tertiary E Learning Research Group. He led the New Zealand delegation to APEC on Bridging the Digital divide and has consulted with the Governments of Oman and Puerto Rico on e-learning matters. 